\title{
Case management as a high-risk prenatal care strategy
}

\author{
Gestão de caso como estratégia de cuidado no pré-natal de alto risco \\ Gestión de caso como estrategia de cuidado en el prenatal de alto riesgo
}

Leticia Gramazio Soares'
ORCID: 0000-0002-7347-0682

leda Harumi Higarashi"

ORCID: 0000-0002-4205-6841

'Universidade Estadual do Centro-Oeste. Guarapuava, Paraná, Brasil.

"Universidade Estadual de Maringá. Maringá, Paraná, Brasil.

How to cite this article:

Soares LG, Higarashi, IH. Case management as a high-risk prenatal care strategy. Rev Bras Enferm. 2019;72(3):692-9.

doi: http://dx.doi.org/10.1590/0034-7167-2018-0483

\section{Corresponding Author:}

Leticia Gramazio Soares

E-mail: leticiagramazio13@gmail.com

Submission: 06-10-2018 Approval: 01-20-2019

\section{ABSTRACT}

Objective: to discuss the benefits of using high-risk prenatal case management. Method: a qualitative, convergent care study with six high-risk pregnant women, performed in a municipality in the south of Brazil. Data were produced by case management from April to August of 2017 through observation-participant. Analysis followed the processes of Convergent Care Research: apprehension, synthesis, theorization and transfer. Results: case management identified important elements in the care of pregnant women, which denoted a greater complexity to the cases; was shown as a relevant space for nurses to act, because it is an intervention that requires knowledge and specific skills. Final considerations: case management provides differentiated management in complex cases, facilitates the flow between health services, concretizing the comprehensiveness and equity of the care. It was found, in the convergence between research and care, that participants were benefited by case management.

Descriptors: Prenatal Care; Maternal Health Services; High-Risk Pregnancy; Maternal and Child Health; Obstetric Nursing.

\section{RESUMO}

Objetivo: discutir os benefícios da utilização da gestão de caso no pré-natal de alto risco. Método: pesquisa qualitativa, convergente assistencial, com seis gestantes de alto risco, realizada num município do Sul do Brasil. Os dados foram produzidos pela gestão de caso, de abril a agosto de 2017, por meio de observação participante. A análise seguiu os processos da Pesquisa Convergente Assistencial: apreensão, síntese, teorização e transferência. Resultados: a gestão de caso identificou elementos importantes no cuidado às gestantes, os quais denotaram maior complexidade aos casos; se mostrou como um espaço pertinente para o enfermeiro atuar, por se tratar de uma ação interventiva que requer conhecimento e habilidades específicas. Considerações finais: a gestão de caso proporciona manejo diferenciado em casos complexos, facilita o fluxo entre os serviços de saúde, concretizando a integralidade e equidade do cuidado. Constatou-se, na convergência entre pesquisa e assistência, que as participantes foram beneficiadas pela gestão de caso.

Descritores: Cuidado Pré-Natal; Serviços de Saúde Materna; Gravidez de Alto Risco; Saúde Materno-Infantil; Enfermagem Obstétrica.

\section{RESUMEN}

Objetivo: discutir los beneficios de la utilización de la gestión de casos en el prenatal de alto riesgo. Método: investigación cualitativa, convergente asistencial, con seis gestantes de alto riesgo, realizada en un municipio del sur de Brasil. Los datos fueron producidos por la gestión de casos, de abril a agosto de 2017, por medio de observación participante. El análisis siguió los procesos de la Investigación Convergente Asistencial: aprehensión, síntesis, teorización y transferencia. Resultados: la gestión de casos identificó elementos importantes en el cuidado a las gestantes, los cuales denotaron mayor complejidad a los casos; se mostró como un espacio pertinente para el enfermero actuar, por tratarse de una acción intervencionista que requiere conocimiento y habilidades específicas. Consideraciones finales: la gestión de casos proporciona un manejo diferenciado en casos complejos, facilita el flujo entre los servicios de salud, concretando la integralidad y equidad del cuidado. Se constató, en la convergencia entre investigación y asistencia, que las participantes se beneficiaron de la gestión de casos.

Descriptores: Atención Prenatal; Servicios de Salud Materna; Embarazo de Alto Riesgo; Salud Materno-Infantil; Enfermería Obstétrica. 


\section{INTRODUCTION}

Prenatal care is recommended during pregnancy as a strategy to improve maternal and neonatal outcomes, particularly important for pregnant women with moderate to high-risk, as it assists in the control and prevention of adverse outcomes ${ }^{(1)}$. The level of care adopted in this period are responsible for harmful outcomes for obstetric and neonatal health ${ }^{(2-3)}$, which lead to increased morbidity and mortality in this population ${ }^{(4-5)}$.

In Brazil, prenatal care is based on the proposal of the Stork Network (Rede Cegonha), which supports the organization of Maternal and Child Health Care Network (RAS - Rede de Atenção à Saúde), which defines the early intake of the pregnant woman, risk stratification and care in a specialized outpatient clinic. In line with this proposal, the Rede Mãe Paranaense Program guides the care for this population in Paraná State. In addition, the program proposes the guarantee of childbirth through hospital attachment, assuring the child the right to safe birth, as well as to healthy growth and development ${ }^{(6-7)}$.

Despite the implementation of programs and improvements achieved, it is known that many maternal and infant deaths can be avoided through the implementation of proven and effective interventions ${ }^{(3,8)}$. Therefore, it is possible to use case management in high-risk prenatal care. However, there is still little research on case management use, especially with high-risk pregnant women, which is still unpublished in the literature, representing a knowledge gap. However, studies suggest that new strategies are researched to be incorporated into the current body of evidence to improve maternal and child care ${ }^{(9-10)}$, which makes this study feasible.

Case management, conceptualized as a method of care ${ }^{(11)}$, develops between a professional case manager and a person with a very complex health condition and social support network to plan, monitor and evaluate care and coordination options of health care, according to the needs of the person, with the purpose of providing quality, humanized care capable of increasing functional capacity and preserving individual and family autonomy ${ }^{(12)}$. It is usually associated with intensive care and expensive hospitalizations ${ }^{(11)}$.

High-risk pregnancy relevance in the current epidemiological setting; the need to investigate interventions in the care of pregnant women; the structuring of RAS in the country, states and municipalities; and case management use as a possible strategy of care for nurses to develop were aspects that justified this study and defined the following guiding question: what are the benefits brought by prenatal case management use in pregnant women stratified as high-risk?

\section{OBJECTIVE}

This study aims to discuss the benefits of using high-risk prenatal case management.

\section{METHODS}

\section{Ethical aspects}

This research was approved by the Committee of Ethics in Research involving Human Beings of the Universidade Estadual do Centro-Oeste, through Opinion 1,371,944. All participants signed the Free and Informed Consent Form.

\section{Type of study}

This is a qualitative, exploratory and descriptive study, supported by the Convergent Care Research (CCR) method; which maintains in its process a close relationship with the care in order to solve problems, make changes and/or introduce innovations ${ }^{(13)}$.

\section{Methodological framework}

Encounter between research and care is the primary concreteness of CCR, with convergence being its methodological differential, where transposing findings to other care technologies reside or new theorized care practices ${ }^{(14)}$.

The concepts governed by the convergence between research and care were: dialogicity: complex communication process and recognition that knowledge is built through interlocution; expansibility: admits that the initial purpose can be expanded during the dialogical process of research and care; immersibility: immersion of the researcher in care during the investigation; simultaneity: recognizes that research and care occur together but keep their own identities ${ }^{(13)}$. In this study, the convergence between research and care occurred throughout the process, making it possible at the same time to collect information while conducting case management.

\section{Study setting}

The study was carried out in the South region, in a mediumsized municipality of Paraná State. The study started at a high-risk prenatal outpatient clinic, point of the network intended to serve all high-risk pregnant women in the city, where the selection of pregnant women for case management occurred; after selection, the research was carried out in the households of the pregnant women and in the Basic Health Units (BHU) of reference of each participant included in the study.

\section{Data source}

Firstly, 132 high-risk pregnant women were individually interviewed so that it was possible to precisely select pregnant women to be monitored in case management. For this, the following inclusion criteria were established: high-risk pregnant women; residing in the urban area of Guarapuava, over 18 years; presenting one or more uncontrolled maternal conditions and/or presenting pregnancy with fetal malformation; being at least at the 24 th week of pregnancy. Since nine pregnant women met the defined criteria, however, there were two refusals, one due to lack of interest and the other was excluded because it was not at home, even though a previous appointment, totaling six participants, who will be called cases 1, 2, 3, 4, 5 and 6 .

\section{Collection and organization of data}

Data were produced from April to August 2017 through participant observation and field diary recording ${ }^{(15)}$. Data were organized in field notes: Observation Notes $(\mathrm{ON})$ from the participant 
observation; Assistance Notes (AN) from the Nursing Care Plan recorded during and after visits and transcribed into a single corpus.

\section{Work steps}

\section{Data production process}

Case management was based on steps as stated in the literature: case selection and problem identification; preparation and implementation of the Nursing Care Plan; and monitoring the care plan ${ }^{(11)}$. The process was conducted exclusively by a researcher called case manager who was a nurse with experience in maternal and child health and doctoral student.

After selecting the pregnant women, a telephone contact was made to schedule the first visit. By accepting it, case management and data production began. As part of the Nursing Care Plan, socioeconomic, demographic data, as well as health history, obstetrics and current pregnancy were collected, which were included in the plan, so that this evidence could be incorporated into case management.

The relationship establishment moment between participant and case manager was at the home visit. At these meetings, the case manager updated the Nursing Care Plan manually, through nursing consultation to the high-risk pregnant woman, with anamnesis and physical examination, identification of problems and situations, which based the interventions performed by the manager case or by orientation or referral of the identified demands to the health services. Thus, the Nursing Care Plan was monitored and modified at each home visit, according to the dynamics presented by the case. For each pregnant woman, an average of five home visits lasting approximately 40 minutes and frequency adapted to the needs of each case, weekly or biweekly, were performed. All participants continued to be cared for by the health service, according to the municipal protocol. Relatives participated indirectly in the study as non-participants, once they were inserted in the participant observation.

Chart 1 - Synthesis of research work steps for data production, AprilAugust, 2017

\begin{tabular}{|c|l|}
\hline Case management steps & Purpose \\
\hline $\begin{array}{c}\text { Case selection and } \\
\text { problem identification }\end{array}$ & $\begin{array}{l}\text { It allowed selecting the most complex } \\
\text { cases of high-risk pregnancy. }\end{array}$ \\
\hline $\begin{array}{c}\text { Development and } \\
\text { implementation of the } \\
\text { Nursing Care Plan }\end{array}$ & $\begin{array}{l}\text { Home visits were done. The case } \\
\text { manager conducted a nursing } \\
\text { consultation and developed a Nursing } \\
\text { Care Plan, according to the needs of } \\
\text { each pregnant woman, which allowed } \\
\text { for research and care. }\end{array}$ \\
\hline Monitoring of the Nursing \\
Care Plan & $\begin{array}{l}\text { The Nursing Care Plan guided the case } \\
\text { management and made it possible } \\
\text { to carry out care actions, advocate for } \\
\text { the needs and to visualize moments in } \\
\text { which there was convergence between } \\
\text { research and care. }\end{array}$ \\
\hline \multicolumn{2}{|l}{} \\
\hline
\end{tabular}

Records from the field notes of the participant observation made it possible to understand the context in which the participant was inserted, as well as interaction among the actors, pregnant, family, health professionals and case manager, which defined care for pregnant women, data used as a research to leverage the social construction of knowledge. Field notes of the Nursing Care Plan referred to the problems identified in the nursing consultation and care interventions carried out by the case manager, to solve them or minimize them. The needs raised by the case manager set the moment in which the convergence between research and care occurred. Synthesis of the development steps of case management is shown in Chart 1.

\section{Data analysis}

After reading the corpus of the field notes, data analysis was applied by the case manager, which involved four processes ${ }^{(15)}$ : Aprehension: collection of information during the follow-up of pregnant women. Synthesis: detailed reading of the notes transcribed, identification of words/sets with meaning and classification in categories. Conversion of field note information followed the coding rule ${ }^{(15)}$. Theorization: raising the data to a high level of abstraction, by associating them with literature. Transfer: possibility of socializing the results in similar situations. For this, the transmissibility of knowledge must undergo a process of (dis) abstraction, in order to make it fit to materialize the findings.

\section{RESULTS}

The results will be presented initially from a brief description of each case (Chart 2) and, later, by the categories of analysis. Presentation of these aspects aimed to contextualize the reality investigated in order to guide the analysis by categories.

In general, about the group characteristics, only one participant presents was very old; all had companions; all have already experienced the loss of a child, being a child or stillbirth. The Specific Hypertensive Pregnancy Syndrome (SHEG - Síndrome Hipertensiva Específica da Gestação) appears as a high-risk motive in five cases and gestational obesity in three cases.

Chart 2 - Cases description April-August, 2017

\begin{tabular}{|c|}
\hline Case description \\
\hline $\begin{array}{l}\text { Case 1: } 42 \text { years old, married, domestic. Preg 4, Abortion 2, Childbirths } 2 \text {. A } \\
\text { living son and a stillborn. High-risk pregnancy: venous thrombosis, SHEG } \\
\text { and old age. }\end{array}$ \\
\hline $\begin{array}{l}\text { Case 2: } 27 \text { years old, married, domestic. Preg 3, Abortion 0, Childbirths } \\
\text { 3. Two living children and one dead. High-risk pregnancy: SHEG, gesta- } \\
\text { tional diabetes mellitus and obesity (gestational BMI 42,49). }\end{array}$ \\
\hline $\begin{array}{l}\text { Case 3: } 21 \text { years old, married, domestic, smoker. Preg 1. Abortion } 0 \text {. } \\
\text { Childbirth 1. A stillbirth for less than a year. High-risk pregnancy: pre- } \\
\text { term labor, gestational syphilis, and low birth weight. }\end{array}$ \\
\hline $\begin{array}{l}\text { Case } 4: 24 \text { years, married, domestic. Preg 5. Abortion } 1 \text {. Childbirth 4. Liv- } \\
\text { ing children } 3 \text { and stillborn. High-risk pregnancy due to cardiopathy, } \\
\text { SHEG and toxoplasmosis. }\end{array}$ \\
\hline $\begin{array}{l}\text { Case 5: } 29 \text { years old, married, domestic. Preg 1. Abortion 0. Childbirth } \\
\text { 1. A stillborn child. High-risk pregnancy: history of previous eclampsia, } \\
\text { SHEG, obesity (gestational BMI 47) and urinary tract infection. }\end{array}$ \\
\hline $\begin{array}{l}\text { Case 6: } 24 \text { years old, married, domestic and smoker. Preg 1. Abortion } \\
0 \text {. Childbirth 1. A stillborn child. High-risk pregnancy by SHEG, obesity } \\
\text { (gestational BMI: 39.74). }\end{array}$ \\
\hline
\end{tabular}

The analysis process on case management use in high-risk pregnancy gave rise to two categories: behind the stratification of high-risk pregnancy: identification of complex cases; case 
management as a support for nurses' performance in high-risk prenatal care. Next, categories and corpus of the analytical process will be presented, represented in the excerpts from the field notes.

\section{Behind the stratification of high-risk pregnancy: identifi- cation of complex cases}

This category demonstrated that in developing case management in high-risk pregnancy, it is possible to verify multifactorial situations. Despite the risk stratification used by the programs, it is possible to perceive that there are subpopulations made up of more complex cases and exposed to risks that may lead to unfavorable outcomes, imposing the need for greater vigilance and monitoring. Pregnant women characteristics included in the study show a multifaceted and complex reality. It was possible to verify social, economic, housing and environmental problems in the context of participants. ON records present some situations:

Hygiene and cleanliness of the house is precarious. Open sewer (ON C2),

Five people live in a two-room house with no physical structure and sanitary conditions for the growth and development of a child. Extremely precarious socioeconomic conditions (...) (ON C4)

Scarcity of financial resources is a major aggravating factor and interferes with people's basic needs. The needs of the family were provided by the woman, now away from work (ON C6),

Other results showed that, because of lack of knowledge, awareness and/or orientation, pregnant women do not follow care during high-risk pregnancies, such as those described in the ON below:

Patient does not wear elastic socks daily and says he cannot wear shoes. Patient only uses to go to the doctor and does not recognize the benefit of the sock (ON C1).

The pregnant woman was spreading clothes on the clothesline, even when she was in absolute rest. When I check blood pressure, I can smell cigarettes (ON C3).

Patient presents a gestational BMI of 47.65 and does not have alimentary restriction, lacking in consultations with nutritionist. In the afternoon, the pregnant woman ate fried meat dipped in fat. You can see caloric foods at home. The husband is overweight. With history of recurrent urinary tract infection. Patient makes use of parsley tea. Its discredit in relation to antibiotic therapy is attributed to frequent unsuccessful use (ON C5).

As the case manager detected such situations, they were contemplated in the Nursing Care Plan, giving rise to AN. These situations allowed the case manager to carry out care actions in the context of the research, such as verified below:

To guide, in a ludic way, the importance of using elastic socks daily in order to prevent thrombosis. Ask for help from the husband to put on the elastic stockings (AN C1).

To tell social worker about social vulnerability (AN C4 and C6).
To shedule consult with a nutritionist for the pregnant woman, via BHU. To book medical consultation at the BHU, urgently, for evaluation and conduct regarding urinary tract infection. To guide the pregnant woman and spouse in choosing less caloric foods. To guide on intimate hygiene to prevent urinary tract infection. To encourage antibiotics use to treat urinary tract infections. To supervise the treatment. To explain the risk of preterm birth and complications caused by hypertension and urinary tract infection (AN C5).

Home visit performed in the puerperal period to participants of the study also evidenced demands for intervention of the case manager, as recorded in the following notes

Newborns who presented problems with regard to exclusive breastfeeding. Guidelines were developed for handhold, position, time and positioning after feeding, as well as feeding and water intake of the mother (AN 2, 3,4 e 5),

Patient presents pain and phlogistic signs in the surgical incision on the 8th day postpartum. Case reported to the nurse of the BHU (AN C5).

Elevated SBP $(130 / 100 \mathrm{mmHg})$ on the $10^{\text {th }}$ postoperative day without treatment. Case reported to the nurse of the BHU (AN C6).

Some results presented here, which culminated in the configuration of this category, demonstrate that pregnancy presents aspects relevant to the care, besides the biological ones, used in the high-risk stratification. However, these aspects, added to the biological ones, influence obstetric and neonatal health.

\section{Case management as a support for nurses' performance in high-risk prenatal care}

Case management presented itself as an opportunity for the nurse to follow complex cases of high-risk pregnancy and to act in a resolutive manner in each case. However, it has shown that the nurse, in assuming this role, must master some skills and abilities, such as: decision-making, communication, understanding human nature and diagnosing and resolving health problems. Some results from the Nursing Care Plan monitoring showed clinical complexity of the cases. The AN below prove the finding:

Pain in lower limbs (7/10) and edema (++/4), with difficulty in using compression socks, in high cost anticoagulant therapy. Patient was in prenatal consultation with obstetricians this week. Return marked for more than one month. The consultation was advanced to next week (AN C1).

Patient presented contractions and uterine dilatation and then was hospitalized. At discharge, ultrasonography was requested. He reported difficulty in scheduling the exam. Accomplished the examination advance to obtain results before the consultation (AN C3).

Patient complains of dizziness and headache. BP: $130 / 100 \mathrm{mmHg}$. The last assessment was more than 20 days in the high-risk outpatient clinic. BP was measured at each visit and appointment of the BHU as a matter of urgency (AN C6). 
Possessing knowledge about obstetric diseases, recognizing signs and symptoms, and being able to make decisions were relevant attributes to the case manager. The ON of case 6 shows this situation, demanding that the periodicity of consultations be increased. However, the pregnant woman received no guidance, no instructions for action at the $\mathrm{BHU}$, not even for blood pressure measurement:

At 33 weeks, BP presented BP 130/100 $\mathrm{mmHg}$, dizziness, headache and vomiting. Hospitalized. Proteinuria. Edema in lower limbs There was a change in the medication used. Obstetric appointments will occur weekly. Anxious about the situation. Blood pressure monitoring only at the outpatient clinic (ON C6).

In this case, the case manager performed the following care action:

To tell the BHU nurse about the pregnant woman's condition. To request that the pregnant woman carry out pressure measure at the BHU once a day; To ask the community health agent to make daily visits to the pregnant woman; To guide the hospital immediately in the presence of signs of increased pressure (AN C6).

Another barrier to high-risk gestational care verified in the study and provided by the case manager concerns health education because it was possible to verify demands of basic orientations among participants, since the participation in groups of pregnant women was null, either by the non-offer or lack of participation. In this way, the case manager is asked the communication skills to guide the pregnant women. The AN below describe this approach:

Guidelines on health education, including: breastfeeding, labor, childbirth, newborn care, feeding (AN C1,2,3,4,5,6); toxoplasmosis (AN C4); management of pre-eclampsia at home (AN C5); intimate hygiene (AN C2, C5); absolute rest (AN C3).

Another aspect relates to the relational role of the case manager, since it is indispensable that the same interact with different professionals from different areas. When advocating for the needs expressed by pregnant women, they should know their rights, as well as the service network.

\section{DISCUSSION}

Another aspect relates to the relational role of the case manager, since it is indispensable that the same interact with different professionals from different areas. When advocating for the needs expressed by pregnant women, they should know their rights, as well as the service network ${ }^{(16-17)}$. Recognizing the breadth of factors affecting pregnancy is to consider the influence of the determinants of life and health of people. Most of the burden of disease and iniquity occurs because of the conditions in which individuals are born, live, work and grow old ${ }^{(18)}$, which requires systematized means to meet users' demands.

Caring for high-risk pregnancy can not only consider biological aspects to stratify risk and dictate care behaviors, as we have verified in this study. When the biological aspects are overweight to the determinants of prenatal health, a mismatch is established in relation to the principles and guidelines of the Brazilian Unified Health System (SUS-Sistema Único de Saúde) and the normalization of gestational health care risk ${ }^{(19)}$. The literature confirms that social inequalities are responsible, in part, for the difficulty in achieving SUS principles ${ }^{(20)}$.

Case management in this study demonstrated the presence of social determinants of health in the context of pregnant women, which were not considered in the care provided to this population. In other studies, these determinants have influenced women to have less health care and comply less with prenatal care ${ }^{(21-22)}$. In this study, the centrality of prenatal care resided in medical consultations, without establishing an interface with socioeconomic issues, evidenced by the case manager, which are known to interfere with maternal and child health. Similarly, a Brazilian study concluded that case management also satisfies subjective, emotional, social, and family demands, not just clinical needs ${ }^{(22)}$.

It should be emphasized that the case manager does not have the responsibility to combat the iniquities encountered, given that they are permeated by macro-structural aspects. Many demands evidenced in this study presented a difficult solution, such as those of social origin. However, the case manager advocated for the user through intermediation to reach solutions. It is necessary to plan coordinated and coherent interventions among each other, triggering sectors that influence the social determinants of obstetric health ${ }^{(18)}$. It is in this finding that it is important for sectors to seek strategies to combat inequities. Population stratification regarding social risk is essential when it is desired to overcome health problems ${ }^{(23-24)}$. Since in case management, mutual collaboration should guide the coordination of care to achieve user-centered goals ${ }^{(11)}$. This setting converges to the understanding that the care for the prenatal of high-risk demands to consider the objective and subjective aspects of the pregnant woman $^{(25)}$. However, it was possible to observe actions directed by protocols, and not guided by the health needs of pregnant women; with a predominance of the secondary level, centralized in the high-risk outpatient clinic, to the detriment of the primary level, since there was little or no primary care activity, and this gap is responsible for generating care demands.

This study has shown that obstetric and neonatal care still requires extensive and comprehensive care. Even though it was delineated within the framework of a nationally recognized program, such as the Stork Network, it was possible to verify pregnant women exposed to complex situations, endangering their health and the baby. This means that within a group considered to be at high risk, there is still a small portion, which is still at greater risk, and that the same care recommendations cannot be subject to the larger group.

Thus, some studies question the lack of consideration of the subjective conditions of women imposed by health programs $s^{(26-27)}$, which predisposes to an isolated diagnosis of the context in which the individual is inserted ${ }_{(28)}$ and to a dehumanized view of obstetric and neonatal care ${ }^{(29)}$. In this particularity, the literature justifies that the case manager adds humanization to an oppressive environment by the holistic care and of defense to the user and family ${ }^{(11)}$.

Even if one perceives a homogeneous conduct, based on care flows and protocols, one must consider that health situations are heterogeneous. Standards can be decisive for one segment, generally larger, but not for another, which is smaller and often exposed to unfavorable determinants ${ }^{(29)}$, as verified in this study. However, for the research purposes, the advocacy role of the 
case manager is reinforced, which must overcome the biological aspects. Studies conducted outside Brazil also showed advocacy for users' needs in case management ${ }^{(30-31)}$.

Case management also brought as a benefit the reduction of the fragmentation of care, as well as in another reality of care outside Brazil(32). Care fragmentation has been pointed out in the literature as one of the major obstacles to RAS. The population coexists with access problems that compromise the continuity of attention between different points ${ }^{(33)}$. In obstetric situations where fragmentation has emerged, case management has found room to be developed, enhancing RAS through referrals and scheduling.

Although the basis of this study ${ }^{(11)}$ considers that case management can be conducted by other professionals, with regard to nursing, the role played by nurses, but also social workers is highlighted. In the case of nursing, it can be explained by the similarities of this approach with the Nursing Process. The development and monitoring of the Nursing Care Plan by the case manager requires critical thinking skills, technical-scientific knowledge, logical reasoning, clinical experience, patient knowledge, application of standards, and contextual perspective ${ }^{(34)}$. Nursing often identifies the limitations of health services, but found in this dilemma an opportunity to expand its practice, such as in case management ${ }^{(11)}$. The role of nurse case manager is identified in international studies ${ }^{(36-38)}$ and still timidly in national surveys ${ }^{(22,37)}$.

Absence or scarcity of health education activities also accounted for the predominance of medical consultations among pregnant women, and this gap required the role of health educator of the case manager, a fact also highlighted in the literature ${ }^{(30)}$. Guidelines on practices to facilitate delivery are relevant to the promotion of vaginal delivery and prevention of early weaning ${ }^{(2)}$.

Although this study did not take into account the measurement of economic results and gestational outcomes, positive effects were observed. The literature highlights meaningful improvements in relation to user satisfaction with treatment, reduction of hospitalizations and expenses, control of symptoms, and even modification of lifestyles ${ }^{(38-39)}$. These characteristics project other developments for case management, either through the development of technologies, as in the USA, where software has already been developed in this perspective, or through the influence of other sectors concerned with care qualification, growing more and more ${ }^{(11)}$ as it has been shown to positively affect health care outcomes $^{(30)}$.

\section{Study limitations}

As limitations of the study, the difficulty in solving some of the demands that have made a backdrop to this reality, especially those of a social nature, is highlighted, possibly because they are macro-structural. Regarding the method, the researcher's performance also encountered some obstacles, such as little attention given by some RAS professionals to the problems evidenced by the case manager, which is crucial for case management.

\section{Contributions to the fields of Nursing, Health or Public Policy}

Case management can be used in other complex care situations that require systematic, longitudinal, comprehensive and qualified follow-up, in order to manage risks and reduce morbidity and mortality. The case manager contributed to improve the flow of high-risk pregnant women in the points of RAS.

\section{CONCLUSION/FINAL CONSIDERATIONS}

Case management use was shown to be promising as a high-risk prenatal care strategy. In particular, in recognizing the subjectivities of each case and understanding the importance of differential management in these cases, concretizing the comprehensiveness and equity of care. It is concluded that among a high-risk population, some pregnant women coexist with complex clinical and social conditions, which require a differentiated care, since they are more susceptible to unfavorable outcomes.

Case management encompassed the recognition of the complexity of high-risk pregnancy through its individualized attention and continuous monitoring of the Nursing Care Plan by establishing standards and practices for the management of complex clinical conditions. To do so, the case manager requires specific skills and abilities. It was possible to verify that case management contributed to care optimization. Although the results were not quantified, the dissolution of critical nodes or obstructions of the attention flow through the intervention of the case manager were evident.

\section{FUNDING/ACKNOWLEDGMENT}

Without funding and without thanks.

\section{REFERENCES}

1. Till SR, Everetts D, Haas DM. Incentives for increasing prenatal care use by women in order to improve maternal and neonatal outcomes. Cochrane Database Syst Rev [Internet]. 2015 [cited 2017 Oct 10];12(2):CD009916. Available from: http://dx.doi.org/10.1002/14651858. CD009916.pub2

2. Viellas EF, Domingues RMSM, Dias MAB, Gama SGN, Filha MMT, Costa JV. Prenatal care in brazil. Cad Saúde Pública [Internet]. 2014 [cited 2017 Oct 29];30(Sup):S1-S15. Available from: http://dx.doi.org/10.1590/0102-311X00126013

3. Salge AKM, Silva RCR, Guimarães JV, Ramalho WS, Abdalla DR, Abdalla GR. Relationship between clinical, placentary, obstetric and neonatal aspects and intrauterine growth in high risk pregnancies. Texto Contexto Enferm [Internet]. 2017 [cited 2017 Nov 04];26(2):e5520015. Available from: http://dx.doi.org/10.1590/0104-07072017005520015

4. Reis ZS, Lage EM, Aguiar RA, Gaspar JS, Vitral GL, Machado EG. [Association between risk pregnancy and route of delivery with maternal and neonatal outcomes]. Rev Bras Ginecol Obstet [Internet]. 2014 [cited 2017 Nov 04];36(2):65-71. Available from: http://www.scielo.br/pdf/ rbgo/v36n2/0100-7203-rbgo-36-02-00065.pdf Portuguese. 
5. Demitto MO, Gravena AAT, Dell' Agnolo CM, Antunes MB, Pelloso SM. High risk pregnancies and factors associated with neonatal death. Rev Esc Enferm USP [Internet]. 2017 [cited 2017 Oct 04];51:e03208. Available from: http://dx.doi.org/10.1590/s1980-220x2016127103208

6. Ministério da Saúde (BR), Secretaria de Atenção à Saúde. Manual prático para implementação do Programa Rede Cegonha. Brasília (DF): 2011

7. Secretaria de Estado da Saúde (PR), Superintendência de Atenção à Saúde. Linha Guia Rede Mãe Paranaense [Internet]. 6 ed. Paraná: Secretaria de Estado da Saúde, Superintendência de Atenção à Saúde; 2017 [cited 2017 Jul 05]. Available from: http://www.saude.pr.gov.br/ arquivos/File/LinhaGuiaMaeParanaense_final_2017.pdf

8. Carlo W, Travers CP. Maternal and neonatal mortality: time to act. J. Pediatr [Internet]. 2016 [cited 2017 Nov 04];92(6):543-45. Available from: http://dx.doi.org/10.1016/j.jped.2016.08.001

9. Das JK, Rizvi A, Bhatti Z, Paul V, Bahl R, Shahidullah M. State of neonatal health care in eight countries of the saarc region, South Asia: how can we make a difference? Paediatr Int Child Health [Internet]. 2015 [cited 2017 Oct 05];35(3):174-86. Available from: https://doi.org/10.1179 /2046905515Y.0000000046

10. Shetty AK. Global maternal, newborn, and child health: successes, challenges, and opportunities. Pediatr Clin North Am [Internet]. 2016 [cited 2017 Nov 05];63(1):01-18. Available from: http://dx.doi.org/10.1016/j.pcl.2015.08.001

11. Powell SK, Tahan HM. Case Management: a practical guide for education of practice. 3a ed. Wolters Klüwer; 2010.

12. Mendes EV. As redes de atenção à saúde. 2a ed. Brasília: OPAS; 2011.

13. Trentini M, Paim L, Da Silva DMGV. Pesquisa Convergente Assistencial: delineamento provocador de mudanças nas práticas de saúde. 3a ed. Porto Alegre: Moriá; 2014.

14. Trentini M, Paim L, Da Silva DMGV. A convergência de concepções teóricas e práticas de saúde: uma reconquista da Pesquisa Convergente Assistencial. Porto Alegre: Moriá; 2017.

15. Yin RK. Pesquisa qualitativa do início ao fim. São Paulo: Penso Editora, 2016.

16. Piveta V, Bernardy CCF, Sodré TM. Perception of pregnancy risk by a group of pregnant women hypertensive hospitalized. Cienc Cuid Saude [Internet]. 2016 [cited 2017 Nov 01];15(1):61-8. Available from: http://dx.doi.org/10.4025/cienccuidsaude.v15i1.28988

17. Goudard MJF, Simões VMF, Batista RFL, Queiroz RCS, Alves MTSSB, Coimbra LC, et al. [Inadequacy of the content of prenatal care and associated factors in a cohort in the northeast of brazil]. Ciênc Saúde Colet [Internet]. 2016 [cited 2017 Sep 05];21(4):1227-38. Available from: http://dx.doi.org/10.1590/1413-81232015214.12512015 Portuguese

18. Carvalho Al. A saúde no Brasil em 2030: prospecção estratégica do sistema de saúde brasileiro [Internet]. Rio de Janeiro: FioCruz; 2013 [cited 2017 Nov 05]. Available from: http://books.scielo.org

19. Ministério da Saúde (BR), Gabinete do Ministério. Portaria n 1.020, de 29 de maio de 2013. Institui as diretrizes para a organização da Atenção à Saúde na Gestação de Alto Risco e define os critérios para a implantação e habilitação dos serviços de referência à Atenção à Saúde na Gestação de Alto Risco, incluída a Casa de Gestante, Bebê e Puérpera (CGBP), em conformidade com a Rede Cegonha [Internet]. Diário Oficial da União: República Federativa do Brasil; 2013 [cited 2019 Mar 17]. Jun 27, Seção 1: p. 109. Available from: http://bvsms.saude. gov.br/bvs/saudelegis/gm/2013/prt1020_29_05_2013.html

20. Giovanella L, Escorel S, Lobato LVC, Noronha JC, Carvalho AI. Políticas e sistemas de saúde no Brasil. 2a ed. Rio de Janeiro: Editora Fiocruz; 2012.

21. Tomasi E, Fernandes PAA, Fischer T, Siqueira FCV, Silveira DS, Thomé E, et al. [Quality of prenatal services in primary healthcare in brazil: indicators and social inequalities]. Cad Saúde Pública [Internet]. 2017 [cited 201 Nov 04];33(3):e00195815. Available from: http://dx.doi. org/10.1590/0102-311x00195815

22. Piovezan M, Bestetti MLTO. [The gerontologist as a case manager: simulation of experiences in distinct and specific studies]. Rev Kairós Gerontol [Internet]. 2012 [cited 2017 Sep 05];15(8):201-16. Available from: https://revistas.pucsp.br/index.php/kairos/article/ view/8872/12677 Portuguese.

23. Gryschek ALFPL, Nichiata LYI, Francolli LA, Oliveira MAF, Pinho PH. [Building the women's health network towards constructing a care line for pregnant and puerperium women in the regional management board of alto Capivari]. Saúde Soc [Internet]. 2014 [cited 2017 Oct 18];23(2): 689-700. Available from: http://dx.doi.org/10.1590/S0104-12902014000200027

24. Fiorati RC, Arcêncio RA, Souza LB. Social inequalities and access to health: challenges for society and the nursing field. Rev Lat Am Enferm [Internet]. 2016 [cited 2017 Nov 04];24:e2687. Available from: http://dx.doi.org/10.1590/1518-8345.0945.2687

25. Carneiro RG. [Anthropological dilemmas of a public health agenda: rede cegonha program, individuality and plurality]. Interface [Internet]. 2013 [cited 2017 Sep 07];17(44):49-59. Available from: http://dx.doi.org/10.1590/S1414-32832013000100005 Portuguese.

26. Souza CR, Botazzo C. [Social construction of health demand]. Physis [Internet]. 2013 [cited 2018 Jun 02];23(2):393-413. Available from: http://dx.doi.org/10.1590/S0103-73312013000200005 Portuguese.

27. Souto KMBS, Sena AGN, Pereira VOMP, Santos LM. State and equity policies in health: participatory democracy? Saúde Debate [Internet]. 2016 [cited 2017 Nov 04];40(nspe):49-62. Available from: http://dx.doi.org/10.1590/0103-11042016s05

28. Santos FAPS, Enders BC, Santos VEP, Dantas DNA, Miranda LSMV. Comprehensive and obstetric care in the unified health system: reflection in the light of edgar morin's complexity theory. Esc Anna Nery [Internet]. 2016 [cited 2017 Sep 04];20(4):e20160094. Available from: http:// dx.doi.org/10.5935/1414-8145.20160094

29. Dodou HD, Rodrigues DP, Guerreiro EM, Guedes MVC, Lago PN, Mesquita NS. The contribution of the companion to the humanization of 
delivery and birth: perceptions of puerperal women. Esc Anna Nery [Internet]. 2014 [cited 2017 Aug 30];18(2):262-9. Available from: http:// dx.doi.org/10.5935/1414-8145.20140038

30. Woodward J, Rice E. Case management. Nurs Clin North Am [Internet]. 2015 [cited 2017 Oct 13];50(1):109-21. Available from: https://doi. org/10.1016/j.cnur.2014.10.009

31. Correa-Casado M, Molina JG, Padilla JMH, Sola CF. Transferring palliative-care patients from hospital to community care: a qualitative study. Atenc Primaria [Internet]. 2016 [cited 2017 Nov 05];49(6):326-34. Available from: https://doi.org/10.1016/j.aprim.2016.09.003

32. Jiménez V, Rosario M, Benavente L, Corominas IH, Ángeles M, Mercedes GR, et al. [Nurse Case Manager Murcia Health Service: A year of program implementation]. Enferm Global [Internet]. 2014 [cited 2017 Nov 02];13(4):57-69. Available from: http://dx.doi.org/10.6018/ eglobal.13.4.169521 Spanish.

33. Santos AM, Giovanella L. [Managing comprehensive care: a case study in a health district in bahia state, brazil]. Cad Saúde Pública [Internet]. 2016 [cited 2017 Nov 15];32(3):e00172214. Available from: http://dx.doi.org/10.1590/0102-311X00172214 Portuguese.

34. Bittencourt GKGD, Crossettill MGO. Critical thinking skills in the nursing diagnosis process. Rev Esc Enferm USP [Internet]. 2013 [cited 2017 Oct 16];47(2):337-43. Available from: http://dx.doi.org/10.1590/S0080-62342013000200010

35. Shellman J, Lacey K, Clemmens D. Carelink: Partners in a care model: a cardiac management program for home care. Home Healthc Nurse [Internet]. 2008 [cited 2017 Nov 15];26(10):582-8. Available from: http://dx.doi.org/10.1097/01.NHH.0000341220.02522.30

36. Smith R. Clinical risk management in obstetric practice. Obst Gynaecol Reprod Med[Internet]. 2017 [cited 2017 Nov 03];27(9):277-84 Available from: http://dx.doi.org/10.1016/j.ogrm.2017.06.011

37. Moreira RC, Mantovani MF, Soriano JV. Nursing case management and glycemic control among brazilians with type 2 diabetes: pragmatic clinical trial. Nurs Res [Internet]. 2015 [cited 2017 Sep 30];64(4):272-81. Available from: http://dx.doi.org/10.1097/NNR.0000000000000104

38. Grover CA, Crawford E, Close RJH. The efficacy of case management on emergency department frequent users: an eight-year observational study. J Emerg Med [Internet]. 2016 [cited 2017 Sep 06];51(5):595-604. Available from: https://doi.org/10.1016/j.jemermed.2016.06.002

39. Askerud A, Conder J. Patients experiences of nurse case management in primary care: a metasynthesis. Aust J Prim Health [Internet]. 2017 [cited 2017 Nov 30];23(5):420-28. Available from: https://doi.org/10.1071/PY17040 